\title{
The Emergence of Industrial Marketing Management as the Leading Academic Journal in Business-to-Business Marketing
}

Di Benedetto, C. Anthony; Lindgreen, Adam

\author{
Document Version \\ Accepted author manuscript \\ Published in: \\ Industrial Marketing Management \\ DOI: \\ 10.1016/j.indmarman.2018.01.023 \\ Publication date: \\ 2018 \\ License \\ CC BY-NC-ND
}

Citation for published version $(A P A)$ :

Di Benedetto, C. A., \& Lindgreen, A. (2018). The Emergence of Industrial Marketing Management as the Leading Academic Journal in Business-to-Business Marketing. Industrial Marketing Management, 69, 5-12. https://doi.org/10.1016/j.indmarman.2018.01.023

Link to publication in CBS Research Portal

\section{General rights}

Copyright and moral rights for the publications made accessible in the public portal are retained by the authors and/or other copyright owners and it is a condition of accessing publications that users recognise and abide by the legal requirements associated with these rights.

\section{Take down policy}

If you believe that this document breaches copyright please contact us (research.lib@cbs.dk) providing details, and we will remove access to the work immediately and investigate your claim. 


\section{The Emergence of Industrial Marketing Management as the Leading Academic Journal in Business-to-Business Marketing}

\section{Anthony Di Benedetto and Adam Lindgreen}

Journal article (Accepted manuscript*)

\section{Please cite this article as:}

Di Benedetto, С. A., \& Lindgreen, A. (2018). The Emergence of Industrial Marketing Management as the Leading Academic Journal in Business-to-Business Marketing. Industrial Marketing Management, 69, 5-12. DOl: 10.1016/j.indmarman.2018.01.023

DOI: 10.1016/j.indmarman.2018.01.023

* This version of the article has been accepted for publication and undergone full peer review but has not been through the copyediting, typesetting, pagination and proofreading process, which may lead to differences between this version and the publisher's final version AKA Version of Record.

Uploaded to CBS Research Portal: February २०19

(C) 2019. This manuscript version is made available under the CC-BY-NC-ND 4.0 license http://creativecommons.org/licenses/by-nc-nd/4.0/ 
The Emergence of Industrial Marketing Management as the Leading Academic Journal in

\section{Business-to-Business Marketing}

C. Anthony Di Benedetto, Fox School of Business, Temple University ${ }^{1}$

Adam Lindgreen, Copenhagen Business School and University of Pretoria's Gordon Institute of Business Science $^{2}$

Acknowledgements: The authors thank Dylan Pesce and Rourke Phelan, students at the Fox School of Business, Temple University, for their assistance in the preparation of this manuscript.

${ }^{1}$ C. Anthony Di Benedetto, Department of Marketing and Supply Chain Management, Fox School of Business, Temple University, Alter Hall 523, 1801 Liacouras Walk, Philadelphia, PA 19122-6083, USA. E-mail: tonyd@ temple.edu.

2 Adam Lindgreen, Department of Marketing, Copenhagen Business School, Solbjerg Plads 3, 2000 Frederiksberg C, Denmark and University of Pretoria's Gordon Institute of Business Science, 26 Melville Road, Illovo, Johannesburg, South Africa. E-mail: adli.marktg@cbs.dk. 


\begin{abstract}
During 1994-2016, Peter LaPlaca served as editor-in-chief of Industrial Marketing Management, an era in which the research discipline surrounding business-to-business marketing showed remarkable growth and attracted the attention of scholars worldwide. This article traces the evolving maturity of the discipline during these years by analyzing not just statistics but also the content of the premier journal in this area, Industrial Marketing Management. The number of papers submitted and articles published per year, the growth in the journal's impact factor, the increased presence of international authors and editorial board members, and the arrival of metaanalyses and special issues on emerging research topics all indicate the level of maturity and scope of the business-to-business marketing research discipline attained during this periodthanks to the expert guidance and tireless efforts of Professor LaPlaca as editor-in-chief.
\end{abstract}

Keywords: emerging topics, Industrial Marketing Management, international scope, journal demographics, Peter LaPlaca. 


\section{INTRODUCTION}

Peter LaPlaca took over the duties of editor-in-chief of Industrial Marketing Management in 1994. Twenty-three years later, at the end of 2016, he stepped down, and the two authors of this article assumed his responsibilities as co-editors-in-chief. This statement by itself is indicative of Peter's dedication: His workload was enough to keep two editors busy. In tribute to his hard work over more than two decades of editorship, this article traces the development and maturity of the field of business-to-business marketing, according to the influence Peter has had in shaping our discipline through his expert guidance as the editor of Industrial Marketing

\section{Management.}

The inaugural issue of Industrial Marketing Management appeared in September 1971, for which R. Derek Medford served as the first editor-in-chief. Prior to then, no single journal had been dedicated specifically to academic research in the growing area of business-to-business marketing. In the early days of the development of a body of literature, when the academic discipline is relatively new and becoming established, we expect basic research questions, basic research approaches, and analytical techniques. As the discipline begins to mature, researchers find solutions to the simple research questions, so the scope of their questions broadens. More researchers also enter the discipline, pursuing a broader range of research interests and adopting a wider variety of analytical techniques. The simple methods applied to measure basic constructs (e.g., single-item measures of new product success) get replaced with better measurements (e.g., success can be measured relative to expectations, to competition, to company history, and so on). The expansion and extensions of simple conceptual models provide truer representations of reality; greater data availability both demands and supports improved analytical tools. These observations are hallmarks of the maturation of an academic discipline, along with the 
emergence of meta-analyses. When a research topic has attracted so much academic interest that it merits an overarching study to summarize what is known so far and direct further research, it has achieved a notable state of maturity. We certainly find such evidence of the continued growth and maturity of the business-to-business academic discipline under Peter's leadership, according to each of these criteria.

\section{JOURNAL DEMOGRAPHICS}

A place to begin our assessment of the development of Industrial Marketing Management is with the journal demographics in Table 1. Under Peter's leadership, this journal has grown substantially in all quantitative measures. In his first year of editorship (1994), it published four issues, containing 41 articles and 365 pages. By 2002, the number of issues per year had doubled to eight. By Peter's last year as co-editor-in-chief (2016), Industrial Marketing Management published more than triple the number of articles and total pages. The full information is provided in the tables; we illustrate the remarkable growth of Industrial Marketing Management by focusing on the first three years of Peter's editorship (1994-1996), the year the journal first went to eight annual issues (2002), and his last three years (2014-2016).

During 1994-1996, the number of articles published increased from 41 to 51, boosting the number of issues from four to six and the page count from 365 to 602 pages. We also note a respectable increase in the number of articles submitted for review (from 164 to 232), such that the acceptance rate remained in the range of $21 \%-25 \%$ during this period. Also during this same period, manuscript flows began to increase substantially, reaching 300 submissions by 2002 (an 82\% increase in eight years). Furthermore, 2002 marked the first year that Industrial Marketing Management published eight issues, including 69 articles and 728 pages, representing increases of $68 \%$ and $99 \%$, respectively. In the succeeding decade, growth in submissions, articles, and 
page counts continued at a rapid pace. Since 2014, more than 130 articles and 1,400 pages have been published yearly (in Peter's last year as co-editor-in-chief, 132 articles appeared, totaling 1,556 pages). The submission count peaked at 981 articles in 2014 - a remarkable growth rate of nearly 500\%! This growing popularity of Industrial Marketing Management as a target journal is detailed further in a subsequent section. A changeover to the online submission system in 2015 led to a temporary decrease in the number of submissions, but as of 2016 , the submission count remained steady at 508. Throughout this period, the acceptance rate ranged from $13 \%$ to $26 \%$.

TABLE 1. Journal Demographics, 1994-2016

\begin{tabular}{|r|r|r|r|r|r|r|r|r|}
\hline Year & Volume & \multicolumn{1}{|c|}{ Issues } & Articles & Pages & $\begin{array}{c}\text { Articles } \\
\text { Per } \\
\text { Issue }\end{array}$ & $\begin{array}{c}\text { Pages } \\
\text { Per } \\
\text { Issue }\end{array}$ & $\begin{array}{c}\text { Submissions } \\
\text { Acceptance }\end{array}$ \\
\hline 1994 & 23 & 4 & 41 & 365 & 8.50 & 91.25 & 164 & $25 \%$ \\
\hline 1995 & 24 & 5 & 43 & 458 & 8.60 & 91.60 & 203 & $21 \%$ \\
\hline 1996 & 25 & 6 & 51 & 602 & 8.50 & 100.33 & 232 & $22 \%$ \\
\hline 1997 & 26 & 6 & 47 & 556 & 7.83 & 92.67 & 327 & $14 \%$ \\
\hline 1998 & 27 & 6 & 39 & 528 & 6.50 & 88.00 & 268 & $15 \%$ \\
\hline 1999 & 28 & 6 & 53 & 652 & 8.83 & 108.67 & 271 & $20 \%$ \\
\hline 2000 & 29 & 6 & 51 & 624 & 8.50 & 104.00 & 244 & $21 \%$ \\
\hline 2001 & 30 & 8 & 52 & 660 & 6.50 & 82.50 & 263 & $20 \%$ \\
\hline 2002 & 31 & 8 & 69 & 728 & 8.63 & 91.00 & 300 & $23 \%$ \\
\hline 2003 & 32 & 8 & 67 & 730 & 8.38 & 91.25 & 295 & $23 \%$ \\
\hline 2004 & 33 & 8 & 74 & 785 & 9.25 & 98.13 & 315 & $23 \%$ \\
\hline 2005 & 34 & 8 & 82 & 876 & 10.25 & 109.50 & 335 & $24 \%$ \\
\hline 2006 & 35 & 8 & 87 & 1,036 & 10.88 & 129.50 & 395 & $22 \%$ \\
\hline 2007 & 36 & 8 & 94 & 1,042 & 11.75 & 130.25 & 456 & $21 \%$ \\
\hline 2008 & 37 & 8 & 89 & 1,019 & 11.13 & 127.38 & 528 & $17 \%$ \\
\hline 2009 & 38 & 8 & 101 & 1,024 & 12.63 & 128.00 & 598 & $17 \%$ \\
\hline 2010 & 39 & 8 & 137 & 1,402 & 17.13 & 175.25 & 684 & $20 \%$ \\
\hline 2011 & 40 & 8 & 135 & 1,385 & 16.88 & 173.13 & 717 & $19 \%$ \\
\hline 2012 & 41 & 8 & 119 & 1,310 & 14.88 & 163.75 & 805 & $15 \%$ \\
\hline 2013 & 42 & 8 & 126 & 1,410 & 15.75 & 176.25 & 804 & $16 \%$ \\
\hline 2014 & 43 & 8 & 131 & 1,450 & 16.38 & 181.25 & 981 & $24 \%$ \\
\hline 2015 & $44-51$ & 8 & 138 & 1,616 & 17.25 & 202.00 & 574 & \\
\hline 2016 & $52-59$ & 8 & 132 & 1,556 & 16.50 & 194.50 & 508 & \\
\hline
\end{tabular}


Submission and page counts provide one indication of the growing popularity of Industrial Marketing Management, but another benchmark is the extent to which the articles are used by the academic community. For example, with regard to the number of downloads (Table 2), Industrial Marketing Management articles were downloaded almost 179,000 times in 2004 (the first year for which these data were available) — an average of 2,418 downloads per article. By 2014, this number increased to more than one million downloads annually, and most recently, we find more than 1,150,000 downloads in 2016 alone. In the last three years that we consider, the number of downloads per article averaged around 8,000 (e.g., in 2016, it was 8,738). This impressive total suggests a widening membership of the academic community that is finding Industrial Marketing Management content useful for their own research.

TABLE 2. Article Downloads by Year, 2004-2016

\begin{tabular}{|c|r|c|c|r|}
\hline Year & Downloads & Submissions & Articles & $\begin{array}{r}\text { Downloads } \\
\text { Per Article }\end{array}$ \\
\hline 2004 & 178,934 & 315 & 74 & $2,418.03$ \\
\hline 2005 & 214,725 & 335 & 82 & $2,618.60$ \\
\hline 2006 & 252,876 & 395 & 87 & $2,906.62$ \\
\hline 2007 & 316,532 & 456 & 94 & $3,367.36$ \\
\hline 2008 & 442,992 & 528 & 89 & $4,977.44$ \\
\hline 2009 & 534,594 & 598 & 101 & $5,293.01$ \\
\hline 2010 & 651,483 & 684 & 137 & $4,755.35$ \\
\hline 2011 & 715,031 & 684 & 137 & $5,219.20$ \\
\hline 2012 & 805,976 & 717 & 135 & $5,970.19$ \\
\hline 2013 & 897,926 & 804 & 126 & $7,126.40$ \\
\hline 2014 & $1,045,110$ & 981 & 131 & $7,977.94$ \\
\hline 2015 & $1,105,157$ & 574 & 138 & $8,008.38$ \\
\hline 2016 & $1,153,398$ & 508 & 132 & $8,737.86$ \\
\hline
\end{tabular}

Another familiar benchmark of journal impact is the Thomson ISI Impact Factor, which measures the number of citations of a journal's articles in later publications. Figure 1 depicts the two-year Thomson ISI Impact Factor for Industrial Marketing Management for the period 20022016. It increased most noticeably from 2002 to 2008 , from .500 to a very respectable 1.403 in 
2008. Since that time, the impact factor has climbed even further, remaining around the 1.9 level since 2012. Most recently, in 2016, its Thomson ISI Impact Factor was exactly 1.900.

FIGURE 1. Industrial Marketing Management Thomson ISI Two-Year Impact Factor, 2002-2016

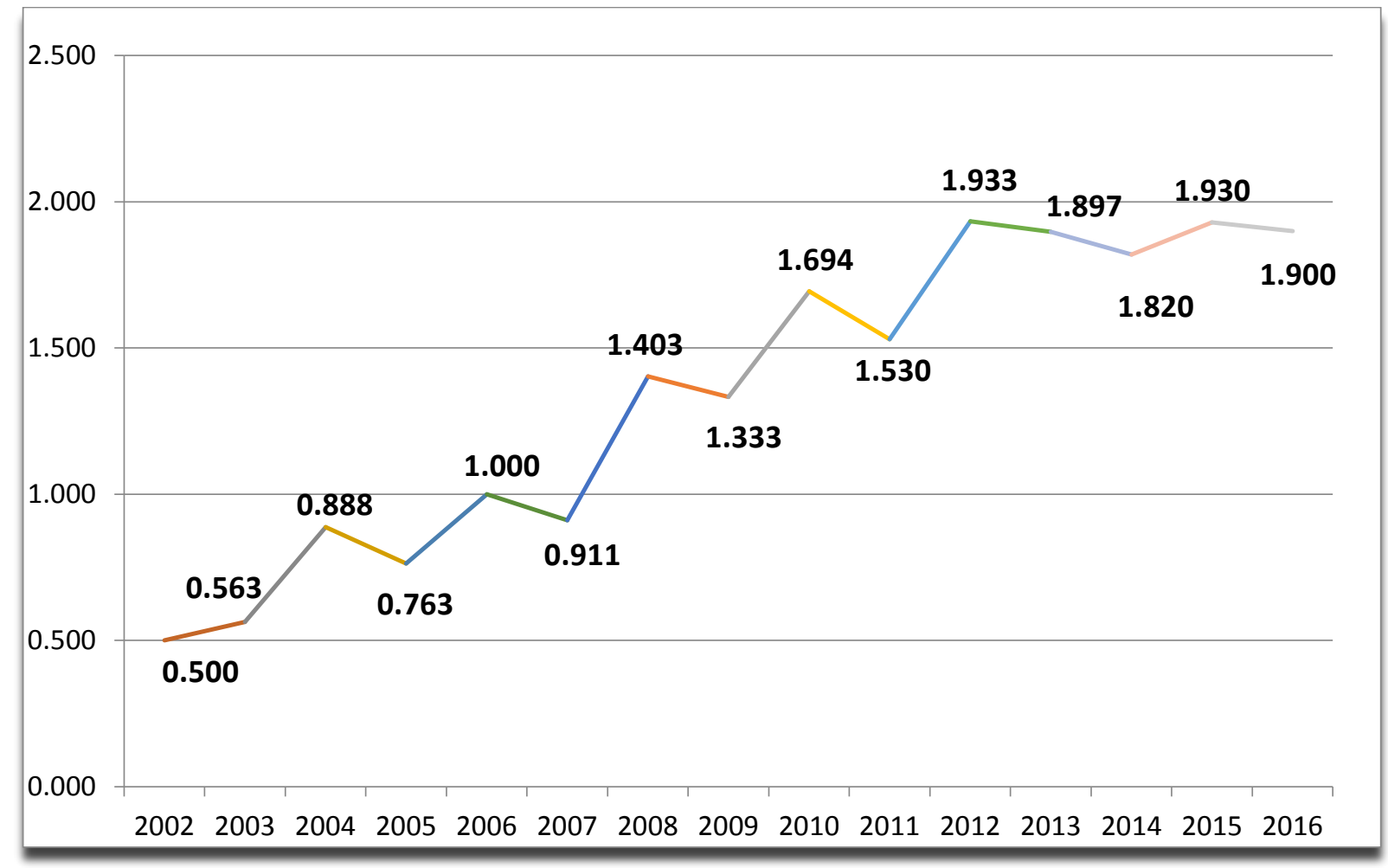

Although the growth of the Thomson ISI Impact Factor in Figure 1 is impressive, it only hints at the growth and expanding influence of Industrial Marketing Management. With the introduction of the Google Scholar search engine, these citation counts have offered an alternative measure of journal impact that provide additional insight. A 2010 article, ranking marketing journals using Google Scholar citations, placed Industrial Marketing Management fifth out of 69 marketing journals (Touzani \& Moussa, 2010). Table 3 lists the top 20 journals according to this study, as well as the top 20 journals in other commonly cited rankings 
(Baumgartner \& Pieters, 2003; Franke \& Schreier, 2008; Guidry, Hollier, Johnson, Tanner, \& Veltsos, 2004).

Touzani and Moussa (2010) note specifically that Industrial Marketing Management earns a substantially higher ranking in their study, using Google Scholar citations, than in the other studies that use different methodologies (Table 3). Their speculation about why Industrial Marketing Management, and a few other journals, rank so highly using the Google Scholar methodology is extremely thought-provoking and suggests some reasons for the remarkable growth we have noted. That is, they propose three reasons, directly attributable to the continued increase in quality and influence of Industrial Marketing Management:

(1) Industrial Marketing Management is read by, and is of interest to, academics in related fields such as strategy, management, innovation, and product development, and thus, it has an influence outside the relatively more narrow field of marketing.

(2) The quality of articles published in Industrial Marketing Management has increased, leading to more citations in recent years.

(3) Research topics covered by Industrial Marketing Management have grown in importance.

In a sense, the strong ranking of Industrial Marketing Management can be taken as evidence of the growing interdisciplinary nature of our journal: Within its pages are published articles that are useful to researchers in a wide range of disciplines, beyond business-to-business marketing. Table 3 also shows that, using Touzani and Moussa's (2010) methodology, Industrial Marketing Management moved to third place among academic marketing journals by 2015.

A final word on rankings, and as additional evidence of the influence of Industrial Marketing Management in the academic community, arises from the meta-ranking of marketing and 
technology journals by Franke and Schreier (2008). These authors combine 18 rankings of business journals, each using different methodologies and criteria, to obtain a meta-ranking that provides a robust ranking of overall journal influence (as of 2008). Table 3 presents the rank ordering of marketing journals included in Franke and Schreier's (2008) article, which places Industrial Marketing Management in a very respectable 14th place.

TABLE 3. Marketing Journal Rankings

\begin{tabular}{|c|c|c|c|c|c|}
\hline Rank & $\begin{array}{l}\text { Baumgartner and } \\
\text { Pieters (2003) }\end{array}$ & Guidry et al. (2004) & $\begin{array}{l}\text { Touzani and } \\
\text { Moussa (2010) }\end{array}$ & $\begin{array}{l}\text { Franke and } \\
\text { Schreier }(2008) *\end{array}$ & $\begin{array}{l}\text { Google Data } \\
\text { Methodology (2015) }\end{array}$ \\
\hline 3 & $\begin{array}{l}\text { Journal of } \\
\text { Consumer Research }\end{array}$ & $\begin{array}{l}\text { Journal of } \\
\text { Consumer Research }\end{array}$ & $\begin{array}{l}\text { Journal of Marketing } \\
\text { Research }\end{array}$ & $\begin{array}{l}\text { Journal of } \\
\text { Consumer Research }\end{array}$ & $\begin{array}{l}\text { Industrial Marketing } \\
\text { Management }\end{array}$ \\
\hline 5 & $\begin{array}{l}\text { Management } \\
\text { Science }\end{array}$ & $\begin{array}{l}\text { Journal of the } \\
\text { Academy of } \\
\text { Marketing Science }\end{array}$ & $\begin{array}{l}\text { Industrial Marketing } \\
\text { Management }\end{array}$ & Marketing Science & $\begin{array}{l}\text { Journal of the } \\
\text { Academy of Marketing } \\
\text { Science }\end{array}$ \\
\hline 6 & $\begin{array}{l}\text { Advances in } \\
\text { Consumer Research }\end{array}$ & Journal of Retailing & $\begin{array}{l}\text { Journal of the } \\
\text { Academy of } \\
\text { Marketing Science }\end{array}$ & $\begin{array}{l}\text { International } \\
\text { Journal of Research } \\
\text { in Marketing }\end{array}$ & $\begin{array}{l}\text { Journal of Consumer } \\
\text { Res. }\end{array}$ \\
\hline 8 & $\begin{array}{l}\text { Journal of the } \\
\text { Academy of } \\
\text { Marketing Science }\end{array}$ & Marketing Letters & $\begin{array}{l}\text { European Journal of } \\
\text { Marketing }\end{array}$ & Journal of Retailing & $\begin{array}{l}\text { European Journal of } \\
\text { Marketing }\end{array}$ \\
\hline 9 & Journal of Retailing & $\begin{array}{l}\text { International } \\
\text { Journal of Research } \\
\text { in Marketing }\end{array}$ & $\begin{array}{l}\text { Journal of Consumer } \\
\text { Psychology }\end{array}$ & $\begin{array}{l}\text { Journal of } \\
\text { Advertising } \\
\text { Research }\end{array}$ & $\begin{array}{l}\text { Journal of Consumer } \\
\text { Psychology }\end{array}$ \\
\hline 10 & $\begin{array}{l}\text { Industrial } \\
\text { Marketing } \\
\text { Management }\end{array}$ & $\begin{array}{l}\text { Journal of } \\
\text { Advertising } \\
\text { Research }\end{array}$ & $\begin{array}{l}\text { Journal of Service } \\
\text { Research }\end{array}$ & Marketing Letters & $\begin{array}{l}\text { Journal of Interactive } \\
\text { Marketing }\end{array}$ \\
\hline 11 & $\begin{array}{l}\text { Journal of } \\
\text { Advertising } \\
\text { Research }\end{array}$ & $\begin{array}{l}\text { Journal of Product } \\
\text { Innovation } \\
\text { Management }\end{array}$ & $\begin{array}{l}\text { Psychology \& } \\
\text { Marketing }\end{array}$ & $\begin{array}{l}\text { Journal of } \\
\text { International } \\
\text { Marketing } \\
\end{array}$ & $\begin{array}{l}\text { Psychology \& } \\
\text { Marketing }\end{array}$ \\
\hline 14 & $\begin{array}{l}\text { Sloan Management } \\
\text { Review }\end{array}$ & $\begin{array}{l}\text { Psychology \& } \\
\text { Marketing }\end{array}$ & $\begin{array}{l}\text { Journal of Interactive } \\
\text { Marketing }\end{array}$ & $\begin{array}{l}\text { Industrial } \\
\text { Marketing } \\
\text { Management }\end{array}$ & $\begin{array}{l}\text { Journal of Service } \\
\text { Research }\end{array}$ \\
\hline 15 & $\begin{array}{l}\text { Journal of } \\
\text { Advertising }\end{array}$ & $\begin{array}{l}\text { Journal of Personal } \\
\text { Selling \& Sales }\end{array}$ & $\begin{array}{l}\text { Journal of } \\
\text { Advertising Research }\end{array}$ & $\begin{array}{l}\text { International } \\
\text { Marketing Review }\end{array}$ & $\begin{array}{l}\text { Journal of Retailing } \\
\text { and Consumer }\end{array}$ \\
\hline
\end{tabular}




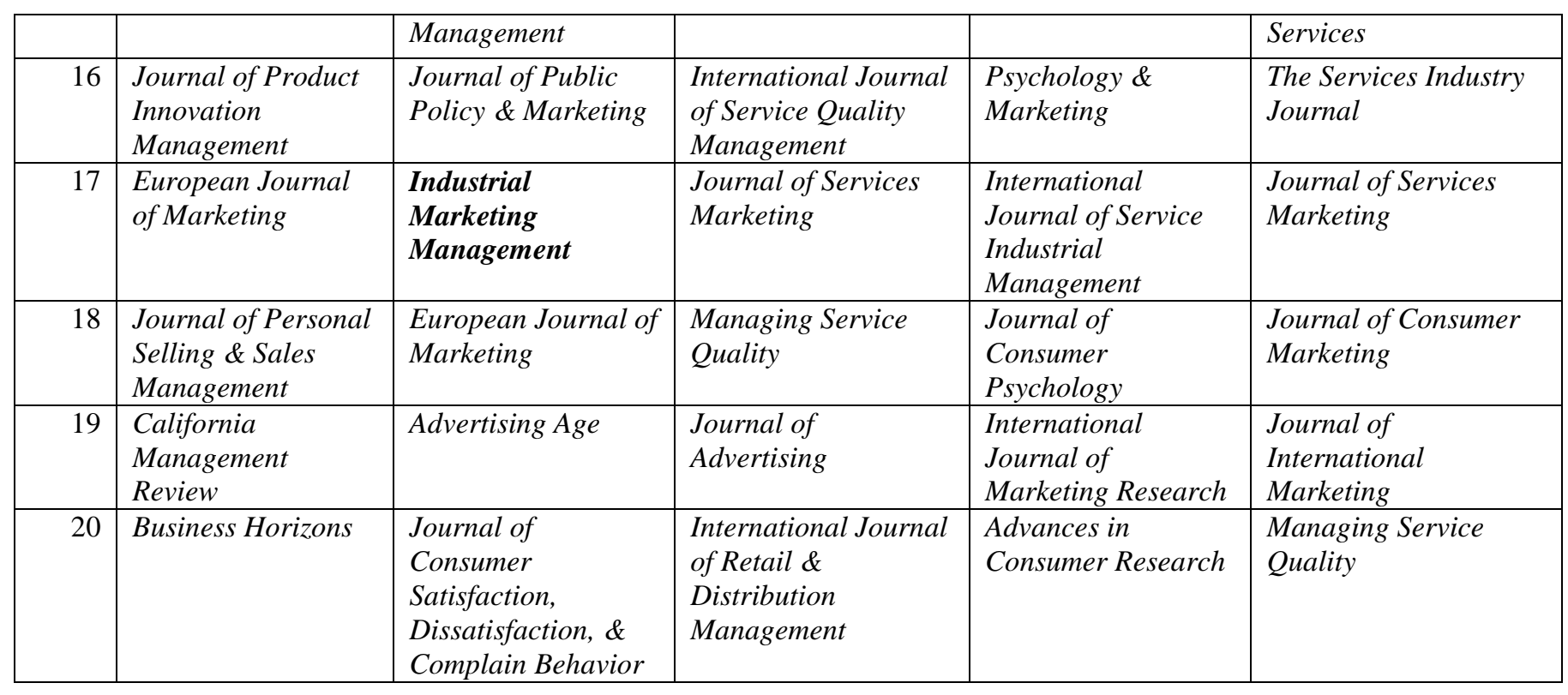

*Includes marketing journals only.

\section{INTERNATIONAL SCOPE}

The preceding section provides evidence of the impressive growth experienced by Industrial Marketing Management under Peter's guidance. Another clear indication that a journal has achieved a position of influence is its international scope, among its editorial board, authors, and readership. As of the last 2016 issue, Industrial Marketing Management's editorial board consisted of 393 academics, of whom 219 (56\%) were based in Europe, 103 (26\%) in the United States, and the remainder from the rest of the world. As Table 4 also shows, the top six countries in terms of the number of editorial board members are the United States, United Kingdom, Finland, Sweden, Australia, and France. In addition, of the five senior editors (two editors-inchief, two associate editors, and one special issue editor), two were based in Denmark and two in the United Kingdom. The editorial board thus is a reflection of the global scope of Industrial Marketing Management. 
TABLE 4. Editorial Board Membership by Country, End of 2016

\begin{tabular}{|c|c|c|}
\hline Editorial Board by Continent & Number & Percentage \\
\hline Europe & 219 & $56 \%$ \\
\hline North America & 110 & $28 \%$ \\
\hline Australia and New Zealand & 27 & $7 \%$ \\
\hline Asia & 24 & $6 \%$ \\
\hline South America & 6 & $2 \%$ \\
\hline Africa & 5 & $1 \%$ \\
\hline Middle East & 2 & $1 \%$ \\
\hline Total & 393 & $101 \%$ (rounding) \\
\hline Editorial Board by Leading Countries & \multicolumn{2}{|r|}{ Number } \\
\hline United States & \multicolumn{2}{|r|}{103} \\
\hline United Kingdom & \multicolumn{2}{|r|}{61} \\
\hline Finland & \multicolumn{2}{|r|}{29} \\
\hline Sweden & \multicolumn{2}{|r|}{26} \\
\hline Australia & \multicolumn{2}{|r|}{17} \\
\hline France & \multicolumn{2}{|r|}{15} \\
\hline Spain & \multicolumn{2}{|r|}{11} \\
\hline Germany & \multicolumn{2}{|r|}{10} \\
\hline New Zealand & \multicolumn{2}{|r|}{10} \\
\hline The Netherlands & \multicolumn{2}{|r|}{9} \\
\hline Hong Kong* & \multicolumn{2}{|r|}{9} \\
\hline Taiwan* & \multicolumn{2}{|r|}{9} \\
\hline
\end{tabular}

* Hong Kong and Taiwan are listed separately from mainland China in these statistics. Taken together, mainland China, Hong Kong, and Taiwan account for 19 board members, 1 of whom is from mainland China.

Table 5 in turn indicates the country of origin of all authors who published in Industrial Marketing Management from 1994 until Peter's last year of co-editorship, 2016. These authorship ranks were about three-quarters U.S.-based in the early years of his tenure (e.g., $72 \%$ U.S.-based in 1994); that is, the large majority of authors were from the journal's country of origin. By 2002, the year that Industrial Marketing Management ramped up to eight annual issues, this percentage of U.S.-based authors had declined to 66\%, and European authors accounted for $21 \%$ of the publications. In the years after 2002 though, the journal began its remarkable expansion into the global market, as evidenced by the authors' countries of origin. 
TABLE 5. Region of Origin of Industrial Marketing Management Authors by Year, 1994-2016

\begin{tabular}{|c|c|c|c|c|c|c|c|c|}
\hline & $\begin{array}{l}\text { United } \\
\text { States }\end{array}$ & Canada & Europe & Asia & $\begin{array}{l}\text { Australia } \\
\text { and New } \\
\text { Zealand }\end{array}$ & $\begin{array}{c}\text { Latin } \\
\text { America }\end{array}$ & Africa & Total \\
\hline 1994 & 60 & 4 & 13 & 4 & 1 & 0 & 1 & 83 \\
\hline 1995 & 56 & 8 & 13 & 8 & 1 & 0 & 2 & 88 \\
\hline 1996 & 65 & 7 & 11 & 1 & 6 & 0 & 0 & 90 \\
\hline 1997 & 70 & 4 & 21 & 0 & 2 & 0 & 2 & 99 \\
\hline 1998 & 48 & 3 & 17 & 2 & 5 & 1 & 2 & 78 \\
\hline 1999 & 73 & 3 & 31 & 3 & 3 & 1 & 0 & 114 \\
\hline 2000 & 55 & 1 & 45 & 4 & 5 & 0 & 0 & 110 \\
\hline 2001 & 54 & 1 & 49 & 1 & 3 & 0 & 1 & 109 \\
\hline 2002 & 90 & 2 & 29 & 4 & 9 & 0 & 3 & 137 \\
\hline 2003 & 57 & 5 & 76 & 2 & 8 & 0 & 0 & 148 \\
\hline 2004 & 72 & 3 & 70 & 6 & 10 & 0 & 2 & 163 \\
\hline 2005 & 91 & 4 & 56 & 14 & 11 & 0 & 0 & 176 \\
\hline 2006 & 43 & 2 & 112 & 32 & 10 & 0 & 1 & 200 \\
\hline 2007 & 53 & 6 & 119 & 28 & 17 & 0 & 0 & 223 \\
\hline 2008 & 75 & 3 & 82 & 63 & 8 & 0 & 0 & 231 \\
\hline 2009 & 61 & 3 & 134 & 29 & 10 & 1 & 1 & 239 \\
\hline 2010 & 74 & 12 & 164 & 54 & 20 & 3 & 2 & 329 \\
\hline 2011 & 55 & 3 & 181 & 60 & 47 & 13 & 7 & 366 \\
\hline 2012 & 52 & 12 & 201 & 44 & 20 & 1 & 1 & 331 \\
\hline 2013 & 45 & 3 & 219 & 27 & 22 & 7 & 0 & 323 \\
\hline 2014 & 78 & 7 & 193 & 47 & 25 & 2 & 5 & 357 \\
\hline 2015 & 54 & 3 & 258 & 55 & 16 & 3 & 4 & 393 \\
\hline 2016 & 46 & 2 & 281 & 15 & 37 & 2 & 4 & 387 \\
\hline Total & 1,427 & 101 & 2,375 & 503 & 296 & 34 & 38 & 4,774 \\
\hline Percentage & $30 \%$ & $2 \%$ & $50 \%$ & $11 \%$ & $6 \%$ & $1 \%$ & $1 \%$ & $100 \%$ \\
\hline
\end{tabular}

By $2014,54 \%$ of authors were of European origin; this percentage had increased to $73 \%$ by 2016. Authors of Asian and Australian/New Zealand origins also increased during this period. 
Overall, during the full tenure of Peter's editorship, 22\% of authors claim the United States as their home region, $50 \%$ are from European countries, $15 \%$ come from Asia, and authors from Australia and Canada make up smaller percentages (Table 5). These overall percentages, however, obscure the ascendance of European authors over the last dozen years of Peter's editorship, as are better illustrated in Figure 2.

FIGURE 2. Trends in U.S. versus European Authorship, 1994-2016

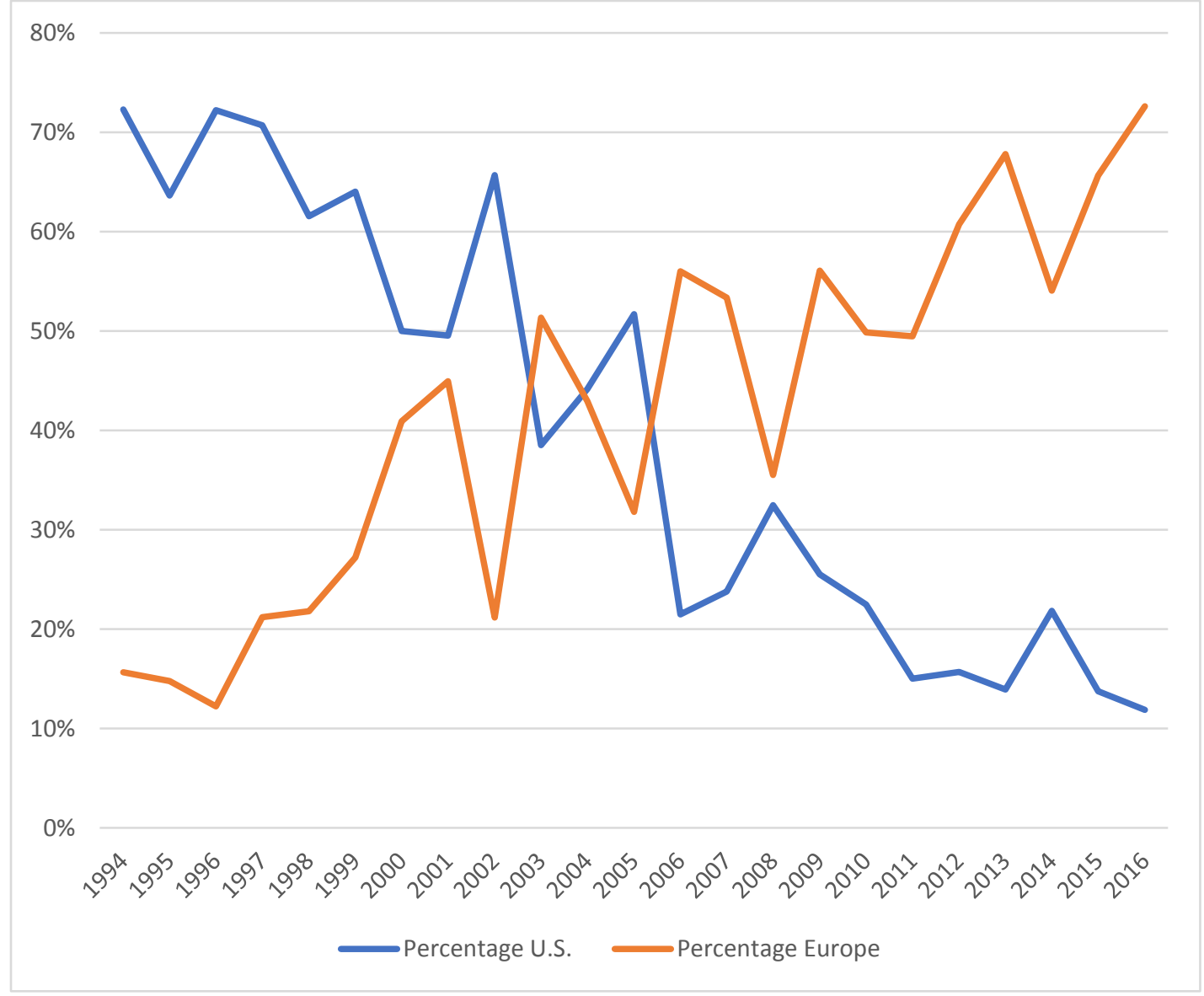

Much of this spread onto the global stage can be attributed to Peter's leadership at IMP conferences. As some of the most important global business-to-business marketing and management academic events, these conferences are well attended by current and future Industrial Marketing Management authors. In the 13 years between 2004 and 2016, 12 annual 
IMP conferences were organized in 11 different European countries; the 2013 IMP conference took place in Atlanta, Georgia. (The full list of all IMP conferences by location appears in Table 6.) Peter's tireless work raised the visibility of Industrial Marketing Management among European marketing academics. He encouraged the authors of the best conference papers to consider sending their research to Industrial Marketing Management, thereby putting the journal on the radar as a top target for high quality business-to-business marketing research. The results of Peter's hard work in building the reputation of Industrial Marketing Management among European marketing academics are thus evident.

TABLE 6. IMP Conference Locations With Industrial Marketing Management Representation Since 2004

\begin{tabular}{|l|l|}
\hline Year & Location \\
\hline 2004 & Copenhagen, Denmark \\
\hline 2005 & Rotterdam, Netherlands \\
\hline 2006 & Milan, Italy \\
\hline 2007 & Manchester, UK \\
\hline 2008 & Uppsala, Sweden \\
\hline 2009 & Budapest, Hungry \\
\hline 2010 & Glasgow, Scotland \\
\hline 2011 & Marseille, France \\
\hline 2012 & Rome, Italy \\
\hline 2013 & Atlanta, Georgia, US \\
\hline 2014 & Bordeaux, France \\
\hline 2015 & Kolding, Denmark \\
\hline 2016 & Poznan, Poland \\
\hline
\end{tabular}

Finally, examining the country of origin of readers who download Industrial Marketing Management articles provides further evidence of its global reach. In 2012, the most recent year for which country data are available, there were almost 806,000 downloads (a figure that has reached well over 1 million annually). Table 7 presents the top ten countries in terms of country of origin of readers downloading articles. Fully $18 \%$ of downloads originated in the United Kingdom. Australia, China (mainland), Iran, the United States, and Germany each accounted for 
$6 \%-8 \%$ of the downloads, while the Netherlands, Taiwan (counted separately from mainland China), Sweden, and Finland rounded out the top ten, as shown in Table 7. This unquestionably far-reaching list thus spans four continents and includes economically developed as well as developing nations.

TABLE 7. Country of Origin of Industrial Marketing Management Readers, 2012

\begin{tabular}{|l|r|r|}
\hline Country & Downloads & Percentage \\
\hline United Kingdom & 148,859 & $18 \%$ \\
\hline Australia & 61,254 & $8 \%$ \\
\hline China* & 60,266 & $7 \%$ \\
\hline Iran & 58,022 & $7 \%$ \\
\hline United States & 52,116 & $6 \%$ \\
\hline Germany & 44,716 & $6 \%$ \\
\hline Netherlands & 41,844 & $5 \%$ \\
\hline Taiwan* & 30,879 & $4 \%$ \\
\hline Sweden & 27,040 & $3 \%$ \\
\hline Finland & 24,110 & \\
\hline Other & 245,557 & \\
\hline Total & 805,976 & \\
\hline
\end{tabular}

* Taiwan is listed separately from mainland China in these statistics.

\section{EMERGING TOPICS}

Beyond the unprecedented growth of Industrial Marketing Management as an academic journal of global reputation and the outcomes of Peter's efforts and involvement with the IMP conference to enhance the journal's global profile, a journal's editor-in-chief can stimulate growth in several other ways, such as by encouraging special issues or sections. (All articles in a special issue focus on the specific special issue topic; a special section includes a few articles on that topic, as well as a few "regular" articles, in the same issue.) Typically, a "hot," highpotential topic is singled out, and with the permission of the editor-in-chief, guest editors solicit a collection of research articles on the topic, selecting the best of them for publication in the special issue/section. Thus, special issues/sections serve two functions: alert the journal's readers 
to the growing importance of a topic while summarizing what is known so far about it, and present the newest research, often authored by a mix of senior academics and the "best and brightest" of the most recent generation of assistant professors. A special issue/section ideally becomes the "go-to" issue for researchers interested in that topic for many years to come.

Readers of Industrial Marketing Management know that Peter has been a champion of special issues/sections, ensuring that several of them appear nearly every year. Table 8 lists all special issues/sections published during the last three years of Peter's editorship. He actively encourages researchers with a promising idea to organize and edit a special issue or section, thereby increasing the relevance of the research published in Industrial Marketing Management for active academic researchers. As indicated in Table 8, every issue of Industrial Marketing Management during this period either is a special issue or contains a special section, which is both remarkable and indicative of the high level of research activity in newly emerging topics that will continue to shape business-to-business marketing research for years to come. Four of these issues were special issues stemming from IMP conferences; they collected the best manuscripts presented at these conferences. The IMP special issues accordingly have solidified the bond forged by Peter between the journal and this important worldwide conference. The other issues all contain special sections_-virtually a compendium of emerging research topics in business-to-business marketing. 
TABLE 8. Special Issues and Special Sections, 2014-2016

\begin{tabular}{|c|l|}
\hline Year & Special Issue/Section \\
\hline 2014 & Integrating Marketing and Operations for Business Sustainability \\
\hline & Co-opetition: Cooperation and Competition \\
\hline & Innovation in Networks \\
\hline & IMP Asia Conference Special Issue \\
\hline & Application of Institutional Theory in Business Marketing \\
\hline & IMP 2013 Special Issue \\
\hline & Relational Key Account Management \\
\hline & Barriers and Consequences of Radical Innovation \\
\hline 2015 & Market Innovation Processes \\
\hline & $\begin{array}{l}\text { From Strategy Frameworks to Value-In-Use (B2B Marketing and Sales } \\
\text { Management) }\end{array}$ \\
\hline & $\begin{array}{l}\text { Accounting and Marketing Perspectives of Value Creation in Inter-Firm } \\
\text { Collaboration in Industrial Markets }\end{array}$ \\
\hline & Behavioral and Psychological Aspects of B2B Pricing \\
\hline & Interplay Between Cognition, Action, and Outcomes in Business Markets \\
\hline & IMP 2014 Special Issue \\
\hline & Innovation in Emerging Markets \\
\hline & Corporate Industrial Brands In, From, and To Emerging Markets \\
\hline 2016 & Servitization and Deservitization \\
\hline & Managing Coopetition: Transcending a Paradox \\
\hline & Social Media and Social Networking in Industrial Marketing \\
\hline & The Dark Side of Relationships \\
\hline & Theory and Practice of Value Co-Creation in B2B Systems \\
\hline & Coopetition in Industrial Markets \\
\hline & IMP 2015 Special Issue \\
\hline & Performance Contracting \\
\hline
\end{tabular}

Space does not permit us to discuss of every one of these special sections, but a few notable trends emerge from the list in Table 8. First, no less than three issues (one in 2014, two in 2016) focus on coopetition, or cooperative competition. This recent growth of interest in coopetition among business-to-business marketing researchers is not surprising; in the modern business world, firms seek more efficient ways to create customer value. Coopetition recognizes that competitors who cooperate, on innovative research and knowledge acquisition, can jointly 
benefit, even if they continue to compete with regard to how they exploit the resulting knowledge. The advantages of coopetition include reduced costs and the efficient use of resources. Pressures to increase productivity and efficiency, in combination with the potential benefits and dangers of working cooperatively with direct competitors, make the topic of coopetition increasingly critical for both practitioners and academic researchers. More general topics related to value creation and value-in-use also have been the focus of a few special issues in this period (one in 2014, two in 2015, one in 2016). Central to any definition of marketing centers is customer value creation (Kotler \& Keller, 2012), and especially in industries marked by increasing technological or market turbulence, firms have sought creative ways to provide value more efficiently. For example, they might seek to access the know-how of suppliers, distributors, or other outside firms in an open innovation arrangement (Chesbrough, 2003).

The topic of business-to-business product innovation for emerging markets also has merited two special sections, both in 2015. Marketing to the bottom of the pyramid represents an emerging topic in general marketing and strategy literature (Prahalad, 2010), in that it poses a notable marketing challenge: how to develop and market products to the bottom one-third of the world's population, in terms of resources, who are in great need but live on subsistence level incomes? The implications of bottom-of-the-pyramid marketing for business-to-business firms thus have drawn recent research attention, such that special sections of Industrial Marketing Management have covered pertinent topics such as processes and barriers in business-to-business product innovation, the marketing-operations interface, and business-to-business account management. In summary, the variety of topics singled out for special sections attests to the wide-ranging scope of research as business-to-business marketing has developed into a mature discipline. 
Some of the key research topics found in the pages of Industrial Marketing Management and other marketing journals also have received enough academic attention that they have prompted meta-analyses. The existence of meta-analyses is excellent evidence of the maturity of an academic discipline; it means there are enough researchers who have produced sufficient research on a topic that tying these extant findings together in a single analysis is warranted. Three meta-analyses have appeared in the pages of Industrial Marketing Management just in the last years under review (2012-2016). Specifically, Saeed, Yousafzai, Paladino, and De Luca (2015) examine inside-out versus outside-in orientations (i.e., does the firm emphasize internal or external resources and capabilities as sources of competitive advantage?) and their effects on innovation and firm performance. Despite the vast literature they analyzed (i.e., 232 articles included), this study could not specify clearly which orientation enhanced firm performance more. Instead, it provides insights on the relative value of the orientations, as well as the presence of moderating effects such as industry type, economic development of host country, and cultural context. Huang and Tsai's (2014) meta-analysis centers on literature pertaining to technology and marketing synergy, the environmental context, and the new product performance of manufacturing firms. They find evidence that increasing marketing synergy exerts a greater effect on performance than technology synergy, that technology synergy positively affects product advantage, and notably, that further increasing technology and marketing synergies hinders product innovativeness. Finally, Tong and Crosno (2016) conduct a meta-analysis on information asymmetry and sharing and find, among other things, that information asymmetry leads to undesirable outcomes, while information sharing relates to desirable ones. These authors identify several moderating variables too, including organizational setting, product type, and relationship duration. 
Meta-analyses are great indications of popular research topics that have reached a certain level of maturity, but it also is instructive to examine which articles are the most widely read. In 2005, Peter initiated the Outstanding Article award, to recognize the best article of the past year, as judged by the total number of downloads. The complete list of Outstanding Article winners through 2016 appears in Table 9. A glance at the research topics represented by these articles is instructive, in that it suggests which business-to-business marketing topics are currently "hot" and inspiring further research. It would be interesting, for a future assessment, to identify how these Outstanding Articles correlate with meta-analyses some years into the future. The first Outstanding Article examined customer value, a topic critical to the practice of marketing management but still in need of more focused research (Lindgreen \& Wynstra, 2005). Several other Outstanding Articles investigated customer value or customer relationship management, in one form or another (Flint, Blocker, \& Boutin, 2011; Gil, Berenguer, \& Cervera, 2008; Kim \& Kim, 2009; Lin, Su, \& Chien, 2006; Richards \& Jones, 2007; Wagner \& Benoit, 2015). Two focused on sustainability and green marketing issues (Chan, He, \& Wang, 2012; Sharma, Iyer, Mehrotra, \& Krishnan, 2010); coopetition, the topic that merited two recent special issues, was the focus of the 2014 winners, Ritala, Golnan, and Wegman (2014). Overall, these topics are among those subjects that have received notable research attention. Any article that has been downloaded enough times to be selected as an award winner is potentially a source of inspiration for new research directions. 
TABLE 9. List of Industrial Marketing Management Outstanding Articles, 2005-2016

\begin{tabular}{|c|c|c|c|c|}
\hline Year & Outstanding Article & Authors & Issue & Pages \\
\hline 2005 & $\begin{array}{l}\text { Value in Business Markets: What Do We } \\
\text { Know? Where Are We Going? }\end{array}$ & $\begin{array}{l}\text { A. Lindgreen and F. } \\
\text { Wynstra }\end{array}$ & 34(7) & $732-748$ \\
\hline 2006 & $\begin{array}{l}\text { A Knowledge-Enabled Procedure for } \\
\text { Customer Relationship Management }\end{array}$ & $\begin{array}{l}\text { Y. Lin, H.-Y. Su, } \\
\text { and S. Chien }\end{array}$ & 35(4) & $446-456$ \\
\hline 2007 & $\begin{array}{l}\text { Customer Relationship Management: } \\
\text { Finding Value Drivers }\end{array}$ & $\begin{array}{l}\text { K. Richards and E. } \\
\text { Jones }\end{array}$ & $36(2)$ & $120-130$ \\
\hline 2008 & $\begin{array}{l}\text { The Roles of Service Encounters, Service } \\
\text { Value, and Job Satisfaction in Achieving } \\
\text { Customer Satisfaction in Business } \\
\text { Relationships }\end{array}$ & $\begin{array}{l}\text { I. Gil, G. } \\
\text { Berenguer, and A. } \\
\text { Cervera }\end{array}$ & 37(8) & $921-939$ \\
\hline 2009 & $\begin{array}{l}\text { A CRM Performance Measurement } \\
\text { Framework: Its Development Process and } \\
\text { Application }\end{array}$ & $\begin{array}{l}\text { H.-S. Kim and Y.- } \\
\text { G. Kim }\end{array}$ & 38(4) & $477-489$ \\
\hline 2010 & $\begin{array}{l}\text { Sustainability and Business-to-Business } \\
\text { Marketing: A Framework and Implications }\end{array}$ & $\begin{array}{l}\text { A. Sharma, G.R. } \\
\text { Iyer, A. Mehrotra, } \\
\text { and R. Krishnan }\end{array}$ & 39(2) & $330-341$ \\
\hline 2011 & $\begin{array}{l}\text { Customer Value Anticipation, Customer } \\
\text { Satisfaction and Loyalty: An Empirical } \\
\text { Examination }\end{array}$ & $\begin{array}{l}\text { D. Flint, C. } \\
\text { Blocker, and P. } \\
\text { Boutin }\end{array}$ & 40(2) & $219-230$ \\
\hline 2012 & $\begin{array}{l}\text { Green Marketing and Its Impact on Supply } \\
\text { Chain Management in Industrial Markets }\end{array}$ & $\begin{array}{l}\text { H. K. Chan, H. He, } \\
\text { and W. Wang }\end{array}$ & $41(4)$ & $557-562$ \\
\hline 2013 & $\begin{array}{l}\text { Theory Map of Business Marketing: } \\
\text { Relationships and Networks Perspectives }\end{array}$ & K. Moller & $42(3)$ & $324-335$ \\
\hline 2014 & $\begin{array}{l}\text { Coopetition-Based Business Models: The } \\
\text { Case of Amazon.com }\end{array}$ & $\begin{array}{l}\text { P. Ritala, A. } \\
\text { Golnan, and A. } \\
\text { Wegman }\end{array}$ & $43(2)$ & $236-248$ \\
\hline 2015 & $\begin{array}{l}\text { Creating Value in Retail Buyer-Vendor } \\
\text { Relationships: A Service-Centered Model }\end{array}$ & $\begin{array}{l}\text { J. Eagner and S. } \\
\text { Benoit }\end{array}$ & 44(January) & $166-179$ \\
\hline 2016 & $\begin{array}{l}\text { Social Media: Influencing Customer } \\
\text { Satisfaction in B2B Sales }\end{array}$ & $\begin{array}{l}\text { R. Agnihotri, R. } \\
\text { Dingus, M. Y. Hu, } \\
\text { and M. Krush }\end{array}$ & 53(February) & $172-180$ \\
\hline
\end{tabular}

As a final indicator of the maturation of the business-to-business marketing discipline, in Table 10 we detail the prevalence of case/observational studies, personal interviews, longitudinal analyses, and other qualitative analyses during 2014-2016. That is, the acceptance of a wide variety of research methodologies (not just empirical surveys) offers an indication that researchers with different scientific backgrounds are applying their preferred methodologies to address specific research issues within business-to-business marketing. As Table 10 shows, case studies and interviews constitute a relevant minority of research studies published during these years. Of the 412 articles published, 70 used case study or observational techniques to gather 
data, and 84 articles used field interviews. Thus, these two categories accounted for $17 \%$ and $20 \%$, respectively, of all articles published. In addition, we find evidence that the research quality of the qualitative case analyses published in Industrial Marketing Management has steadily increased over the years (Beverland \& Lindgreen, 2010). Most articles using non-survey techniques were written by non-North American authors. Thus, opening up to the global market appears to have encouraged authors using a wide variety of research techniques to submit their best work to Industrial Marketing Management.

TABLE 10. Numbers of Articles Using Qualitative Methodologies, 2014-2016

\begin{tabular}{|l|l|l|l|l|}
\hline Year & $\begin{array}{l}\text { Case/Observational } \\
\text { Methodology }\end{array}$ & $\begin{array}{l}\text { Interview } \\
\text { Methodology }\end{array}$ & $\begin{array}{l}\text { Longitudinal } \\
\text { Analysis }\end{array}$ & $\begin{array}{l}\text { Other Qualitative } \\
\text { Methodologies }\end{array}$ \\
\hline 2014 & 15 & 26 & 1 & 14 \\
\hline 2015 & 27 & 22 & 2 & 5 \\
\hline 2016 & 28 & 36 & 1 & 3 \\
\hline
\end{tabular}

Taken together, the wider geographical scope, divergence in research methodologies, and appearance of meta-analyses all offers indications of the maturation of the academic research discipline. Under Peter's supervision, Industrial Marketing Management has played a key role in the wider acceptance and increased development of business-to-business marketing, moving through the growth stage of its life cycle, to become a mature academic discipline.

\section{CONCLUSIONS}

Business-to-business marketing is a well-established, mature research discipline. Even a casual look through the pages of a recent issue shows a broad range of sophisticated research questions and advanced research techniques. This article offers specific and more in-depth evidence of the remarkable growth of this discipline since 1994, when Peter took over the duties as editor-in-chief of Industrial Marketing Management. 
Anyone who has worked with Peter already knows the developmental role he has played as Industrial Marketing Management's editor-in-chief. He has been consistently welcoming to junior research scholars from different countries and research traditions, as well as supportive in terms of encouraging the use of different research approaches. He actively forged ties with the annual IMP conference, resulting in a reliable stream of high-quality articles from authors throughout Europe. He also has been extraordinarily supportive of special issues and special sections, which in turn have made Industrial Marketing Management's issues the trendsetters in guiding research in our discipline. He initiated the journal's Outstanding Article award, to honors the article that its readership finds the most useful in terms of advancing business-to-business literature each year. As a result of Peter's hard work and dedication, it is safe to say that a wider range of researchers, from more countries and more research disciplines than ever before, read Industrial Marketing Management, value the research published in its pages, and view it as the strongest target journal for their own best academic research.

\section{ACKNOWLEGMENTS}

As stated in the introduction to this tribute, manuscripts did not go through the normal, rigorous review process.

\section{REFERENCES}

Agnihotri, R., Dingus, R., Hu, M.Y., \& Krush, M. (2016). Social media: Influencing customer satisfaction in B2B sales. Industrial Marketing Management, 53(February), 172-180.

Baumgartner, H. \& Pieters, R. (2003). The structural influence of marketing journals: A citation analysis of the discipline and its subareas over time. Journal of Marketing, 67(April), 123139. 
Beverland, M. \& Lindgreen, A. (2010). What makes a good case study? A positivist review of qualitative case research published in Industrial Marketing Management, 1971-2006. Industrial Marketing Management, 39(1), 56-63.

Chan, H. K., He, H., \& Wang, W. (2012). Green marketing and its impact on supply chain management in industrial markets. Industrial Marketing Management, 41(4), 557-562.

Chesbrough, H. (2003). Open innovation: The new imperative for creating and profiting from technology. Boston, MA: Harvard Business School Press.

Eagner, J. \& Benoit, S. (2015). Creating value in retail buyer-vendor relationships: A servicecentered model. Industrial Marketing Management, 44(January), 166-179.

Flint, D., Blocker, C., \& Boutin, P. (2011). Customer value anticipation, customer satisfaction and loyalty: An empirical examination. Industrial Marketing Management, 40(2), 219-230.

Franke, N. \& Schreier, M. (2008). A meta-ranking of technology and innovation managemententrepreneurship journals. Die Betriebswirtschaft, 68(2), 185-216.

Gil, I., Berenguer, G., \& Cervera, A. (2008). The roles of service encounters, service value, and job satisfaction in achieving customer satisfaction in business relationships. Industrial Marketing Management, 37(8), 921-939.

Guidry, J.A., Hollier, B.N.G., Johnson, L., Tanner, J.R., \& Veltsos, C. (2004). Surveying the cites: A ranking of marketing journals using citation analysis. Marketing Education Review, 14(Spring), 45-59.

Huang, C.T. \& Tsai, K.H. (2014). Synergy, environmental context, and new product performance: A review based on manufacturing firms. Industrial Marketing Management, 43(8), 1407-1419. 
Kim, H.-S. \& Kim, Y.-G. (2009). A CRM performance measurement framework: Its development process and application. Industrial Marketing Management, 38(4), 477-489.

Kotler, P. \& Keller, K.L. (2012). Marketing Management, 14th ed. New York, NY: Pearson.

Lin, Y., Su, H.-Y., \& Chien, S. (2006). A knowledge-enabled procedure for customer relationship management. Industrial Marketing Management, 35(4), 446-456.

Lindgreen, A. \& Wynstra, F. (2005). Value in business markets: What do we know? Where are we going? Industrial Marketing Management, 34(7), 732-748.

Moller, K. (2013). Theory map of business marketing: Relationships and networks perspectives. Industrial Marketing Management, 42(3), 324-335.

Prahalad, C.K. (2010). The fortune at the bottom of the pyramid. Philadelphia, PE: Wharton School Publishing.

Richards, K. \& Jones, E. (2007). Customer relationship management: Finding value drivers. Industrial Marketing Management, 36(2), 120-130.

Ritala, P., Golnan, A., \& Wegman, A. (2014). Coopetition-based business models: The case of Amazon.com. Industrial Marketing Management, 43(2), 236-248.

Saeed, S., Yousafzai, S., Paladino, A., \& De Luca, L.M. (2015). Inside-out and outside-in orientations: A meta-analysis of orientation's effects on innovation and firm performance. Industrial Marketing Management, 47(May), 121-133.

Sharma, A., Iyer, G.R., Mehrotra, A., \& Krishnan, R. (2010). Sustainability and business-tobusiness marketing: A framework and implications. Industrial Marketing Management, 39(2), $330-341$.

Tong, P. Y. \& Crosno, J.L. (2016). Are information asymmetry and sharing good, bad, or context dependent? A meta-analytic review. Industrial Marketing Management, 56(July), 167-180. 
Touzani, M. \& Moussa, S. (2010). Ranking marketing journals using the search engine Google Scholar. Marketing Education Review, 20(3), 229-247.

Wagner, J. \& Benoit, S. (2015). Creating value in retail buyer-vendor relationships: A servicecentered model. Industrial Marketing Management, 44(January), 166-179. 